\title{
Paradoxical Time and Providential History in Shakespeare and Bacon
}

José María Rodríguez García Universidade da Coruña

\begin{abstract}
Few of Shakespeare's tragic characters have had so many detractors as Richard II, who has been variously dismissed as a capricious tyrant, a self-absorbed poet, and a Protean dramatic force whose unpredictable actions at times threaten the structural integrity of the play. This perception has in turn influenced the interpretation of Bolingbroke as a competent antagonist who brings much-needed order to the chaotic universe of the first two acts of Richard II. This essay sides with the minority of defenders of Richard-thecharacter as the central intelligence who exerts the greatest control over the dramatic events as they are represented upon the stage and on the page. In discussing Richard's recourse to constructions of human history imported from providentialist historiography I make ample use of Francis Bacon's own self-representations as the abused Messiah of experimental philosophy.
\end{abstract}

\section{Richard's Plotting of HIStory.}

Taking a cue from E.M.W. Tillyard's 1946 essay on Richard II, later scholars have used a variety of rhetorical approaches to explore a central theme of the play: the interruption of a king's rule by the appearance of a usurper, and the ensuing promise that this rule will be restored at some time in the future. At stake in this argument is nothing short of the possibility that the early modern subject may be capable of planning (and perhaps even controlling) human affairs over long periods of time. Yet due to the scarcity of Renaissance nonliterary texts showing similar constructions of time and subjectivity, Shakespearean criticism has so far been somewhat reluctant to explore the implications of 
these constructions for a more comprehensive Renaissance theory of human action. My contention is that one such set of texts is to be found in Bacon's posthumously published early treatises. For the early Bacon, experimental philosophy has had moments of incipient prosperity that were nevertheless thwarted by the sudden arrival of a usurper-Aristotle. Bacon repeatedly represents himself as being involved in a struggle against Aristotle and his seventeenth-century descendants. This self-representation leads me to the identification of another similarity between the Shakespearean tragic hero and Bacon. Richard attempts to control rhetorically his own undoing by Bolingbroke while simultaneously accepting it and claiming that posterity will vindicate his name. For his part, Bacon acknowledges that his philosophy will be maliciously suppressed by rival epistemologies, for which reason he entrusts to posterity the strengthening and institutional implementation of Baconianism. Both Richard and Bacon articulate their prophecies of rehabilitation and renewal around the time construct known to poststructuralists as the future perfect.

In 2.1 of Richard II the Duke of York warns his sovereign and nephew, King Richard II, against unfairly dispossessing his other nephew, Henry Bolingbroke, Duke of Hereford, of his legitimate inheritance of lands and titles: "Take Hereford's rights away, and take from time/ His charters, and his customary rights;/ Let not to-morrow then ensue to-day:/ Be not thyself. For how art thou a king/ But by fair sequence and succession?" (195-99). Sameness or self-identity-being oneself-is here defined by means of a father-and-son relationship. For York, then, as for "a thousand well-disposed hearts" (2.1.206), a king is responsible for ensuring the uninterrupted linear unfolding of his own lineage at the same time as he protects and safeguards the "fair sequence and succession" of the peerage. But Richard, seeking to add new titles and lands to his personal patrimony, frustrates the expected succession of John of Gaunt, Duke of Lancaster, by his son Henry Bolingbroke. The effect of this violation of an ancestral code of loyalty is that Richard loses the support of that thousand well-disposed hearts. What is more, he manages to antagonize them in such a manner that he ironically becomes the one who is stripped of his succession privileges. He is deposed. This is, to put it briefly, how the dramatic conflict informing Richard 11 evolves through the reversal of positions experienced by the protagonist and his antagonists.

In his cultural-materialist reading of the play, Richard Wilson has called attention to the irony that Richard's innovative economic practices, while meant to affirm and increase his absolutist pretensions, in fact question them. By appropriating the lands and titles of others, and selling them to untitled buyers, Richard turns inalienable ownership rights-including the right to the throne-into contingent, short-lived events. In other words, he moves from an economic practice based on the continuous possession of property by members of the same family to one in which property circulates in a random manner as dictated by the domineering and capricious will of the king (204-08). This change in ownership rights is seen by the aristocracy as a threat to their sense of communal identity, which depends heavily on the uninterrupted transmission of titles and properties from father to son. Indeed, linear time is represented in the play by means of three sets of images and situations: (1) images of progeny and of a father's succession by his son; (2) images of gardening and natural growth; and (3) images of earthly fame. Now Richard perceives the slow and orderly unfolding of linear time as a limitation to the absolutist 
claims of his will. He in fact conceives the gratification of his desires as being necessarily simultaneous with the awakening of those desires, since he considers his royal prerogative to be God-given. The first three acts of the play challenge this fantasy of uncontested power. To give a couple of examples, in 3.2 Salisbury reports to him that his delay in returning from Ireland has caused his soldiers to disband: "One day too late, I fear me, noble lord,/ Hath clouded all thy happy days on earth./ $O$, call back yesterday, bid time return,/ And thou shalt have twelve thousand fighting men!/ To-day, to-day, unhappy day too late..." (3.2.67-71). The second example features another character, the dying John of Gaunt, denying on his deathbed Richard's power to manipulate secular time to his advantage and extend his life beyond its natural limits:

Rich. Why, uncle, thou hast many years to live.

Gaunt. But not a minute, king, that thou canst give:

Shorten my days thou canst with sullen sorrow,

And pluck nights from me, but not lend a morrow;

Thou canst help time to furrow me with age,

But stop no wrinkle in his pilgrimage;

Thy word is current with him for my death,

But dead, thy kingdom cannot buy my breath.

$(1.3 .225-32)$

Using this and other scenes in the play where time becomes a topic of conversation, Ricardo J. Quinones has advanced an argument on temporality based on the traditional view of Richard as a victim of his own selfishness and blindness. For Quinones, Richard's moral flaws would be most apparent in his condition of "fatherless tragic son." He is "neither father nor son" in a dramatic universe where "family is a lifeline whose neglect means disaster" (Renaissance Discovery 314). Richard's main antagonist in the play, Bolingbroke, is also an inverted mirror image of the abusive king: Bolingbroke, through his words and acts, has become precisely the paragon of the dutiful and beloved son. In contrast with Richard, Bolingbroke would have made a "proper use of time" (324-25). For Quinones, the fact that the "potentiality" of time is "neglected" by Richard but used by Bolingbroke to advance his personal interests and (supposedly) those of the realm reveals a central theme of the play, namely, "that man can exercise a firm control over the events of his life, and that the father is the model for such possibilities" (Renaissance Discovery 320). In a later work on the Cain-and-Abel theme in Western literature, Quinones has observed that this theme is reenacted in the conflict between Richard (a shepherd like Abel) and Bolingbroke (a farmer like Cain). The latter, in moving from a callous act of assassination to a sincere expression of remorse, gives closure to the otherwise endless repetition of an archetypal cycle of violence that may have had an immediate historical referent in the War of the Roses (Changes of Cain 81). However compelling it may sound, the popular interpretation of Bolingbroke as a self-redeeming regicide has been questioned in recent years by performance critics such as Harry Berger, Jr., Leonard Barkan, and Alexander Leggatt, among others, all of whom deny Bolingbroke both the capacity to 
control the environment around him and the power to convince a seventeenth-century audience of the legitimacy of his rebellion.

Bolingbroke's status as modern secular hero was first questioned by Tillyard in his influential study, Shakespeare's History Plays (1946). Like Quinones, Tillyard argued that Richard is a medieval character whose political power stems from sacred ceremonies that only he can perform, whereas Bolingbroke is a man of the secular Renaissance who uses a mixture of courtly politics, common sense, and personal courage to challenge Richard (181). But in his essay Tillyard also made a series of fundamental points that some critics of a liberal-humanist persuasion have stubbornly overlooked: (1) Richard II is the most ceremonial and ritualistic of Shakespeare's plays to the point that the principal struggles and battles represented in it are linguistic rather than physical; (2) Shakespeare was surely aware that the main political event in the play is not Richard's tyranny but Bolingbroke's treason; and (3) Shakespeare's treatment of Bolingbroke is perplexing in that his political stature diminishes as the dramatic action progresses: "[Bolingbroke] has no steady policy and having once set events in motion is the servant of fortune. As such, he is not in control of events, though by his adroitness he may deal with the unpredictable as it occurs" (184). Tillyard disagrees with Quinones on the fundamental issue of the degree of control that Bolingbroke keeps over his surroundings. However, Tillyard finds a way out of this interpretive predicament by reducing Richard 11 to a prototype of the great Lancastrian plays-1 \& 2 Henry IV and Henry V-just as Quinones does:

Richard II does its work in proclaiming the great theme of the whole cycle of Shakespeare's History Plays: the beginning in prosperity, the distortion of prosperity by a crime, civil war, and ultimate renewal of prosperity. The last stage falls outside the play's scope ... (185)

The linking of these two moments of prosperity separated by a lapse of chaos and disgrace is of course what interests me in this essay. As Quinones and Tillyard would have it, Shakespeare explored consecutively-in 1, 2 \& 3 Henry VI, Richard II, 1 \& 2 Henry $I V$, and Henry $V$-the implications of disrupting the linear sequentiality of England's prosperity and the necessity of restoring and preserving this prosperity. What is left out of these accounts is the positive valuation that the collapse of an uninterruptedly prosperous history - what in my title I call paradoxical time-acquires in Richard II.

In his monograph-length reading of the play, Harry Berger has argued (I think convincingly) that Richard's attitude toward the old order of the ceremonial monarchy is one of overall contempt:

contempt for the ideology of kingship; contempt for his performance as king--a performance that slandered the ideology and revealed its powerlessness to restrain his abuses; contempt for himself, perhaps in part for having idealistically believed in divinely sanctioned kingship; contempt for those around him who, if they don't actually believe in that idea, continue to invoke it, especially when they want to excuse or justify the inaction that lets him go on slandering it. (52) 
Berger demonstrates that, within the scope of the play's action, it is Richard who has the idea that he should be deposed, not Henry. Thus, Richard maneuvers others into punishing him for having represented a false image of sacred power. At the same time, Berger goes on (and this is where the originality of his argument resides), Richard craftily turns Bolingbroke into a usurper and a traitor-the originator of a cursed, illegitimate lineage. Berger is almost alone among contemporary critics in refusing to grant that Richard ends up "retir[ing] into a world of private fantasy" which is incompatible with the demands of the public world (James Winny, qtd. disapprovingly in Berger 50). Berger further explains how Richard transforms Bolingbroke's plans for a peaceful abdication into a four-stage magnicidal plot. The four goals sought by Richard are "to get himself deposed, [to] pick out a likely 'heir' to perform that service, [to] reward him with the title of usurper, and [to] leave him with a discredited crown" (49).

If Richard is going to be deposed and murdered, then it is he who wants to appear as the engineer of his own undoing. This authorial position is all-important in that it connects present and future in such a way as to transform the nature of the future as "discovery" into a "homecoming"" (Schmidt 72). How does Richard benefit from this movement from unquestioned sovereignty to deposition and on to retroactive rehabilitation? To begin with, Richard steps out of the magical universe of medieval ceremonial power to face a world of relations where he continues to make strategic use of state rituals and formulae pertaining to that medieval world view without necessarily believing in them. In so doing, he secularizes his position as an agent of historical change. It could be said, therefore, that Richard emancipates himself from the theocentric order of the medieval monarchy. Despite Richard's occasional invocations of divine providence, it is quite clear that the human universe depicted in the play is thoroughly secularized (Champion 109; Sinfield 246-47). Providential history appears in the play by analogy with the structure of Richard's will to elicit in his audience, through ritual repetition, the recognition that what is past can be recreated in the future. Richard's imaginative enactment of how his story will be received by posterity is a wish-fulfillment fantasy that, on a purely psychological level, permits him to evade momentarily the constraints of historical time-to pretend that the disruptive changes which have brought him pain and unhappiness are not definitive.

From the moment Richard realizes the imminence of these changes in the form of his deposition, he willingly cooperates in the plotting of his own violent death. Richard knows that in helping Bolingbroke assassinate him, "the crown can be purified, preserved, sent safely beyond Bolingbroke's hands" (Berger 111). To help this design, he concentrates his energies on two tasks: the rehearsal of an ars moriendi routine containing the images of himself by which he would like to be remembered, and the subversive transformation of Bolingbroke's initial plans for an abdication into a sanguinary deposition.

\section{Bacon, Shakespeare, and the Anti-Christ.}

In his earlier writings, Francis Bacon presented the history of philosophy as a series of violent encounters between rival philosophers who were more interested in dominating their predecessors and contemporaries than in discovering the truth. As a result, Bacon 
believed that philosophy developed a chronic state of trauma whose very physicality he described with such words as "abortion," "killing," and "parricide." For example, in the treatise Thoughts and Conclusions (Cogitata et visa [1607; publ. 1653]) Aristotle appears as "the dictator of philosophy" [Lat. fere Dictaturam in philosophia adeptum] (Farrington 83; Works 7.116), and as the ethnic other of the ideal Baconian scientist: "Aristotle, it must be confessed, busied himself, like an Ottoman Turk, in the slaughter of his brethren [Lat. atque illum scilicet Ottomanorum more in fratribus trucidandis occupatum fuisse], and with success. Yet he cannot escape the judgment that must be passed on the Greeks as a whole" (Farrington 84; Works 7.117). In The Refutation of Philosophies (Redargutio philosophiarum [1608; publ. 1734]) Bacon once again calls Aristotle a parricidal author, this time adding that he was also an unlawful ruler who usurped the throne of philosophy: "Aristotle, like the Ottoman Turk, did not think he could reign secure till he had slain his brothers" (Farrington 110). Because of this infamy, Aristotle proved himself to be deserving of the same degree of violence which he had inflicted on others. Thus Bacon asks his audience to murder Aristotle: "Are you too timid to apply to him the rule he applied to his predecessors?" (114). The analogy with Richard II is obvious enough. Bolingbroke deconsecrates the medieval monarchy when he violates the divine right of kings. He thus clears the way for future rebellions against his own authority. This is so because Bolingbroke's authority is that of the usurper.

Bacon calls Aristotle the Anti-Christ of philosophy. Aristotle is "no greater than ... the Prince of Imposture, the Anti-Christ" [Lat. atque Princeps Imposturae Antichristus] (Farrington 113; Works 7.69). It is typical of the Anti-Christ figures that they manage to gather support for their illicit plans while the true Son of God, Christ, is betrayed by his neighbors:

Christ says that he who comes in the name of the Father, which in a true and pious, if not a literal, sense is the name of antiquity [Lat. in nomine paternitatis aut antiquitatis], will not be received, but he who, levelling and destroying all that went before, usurps authority to himself and comes in his own name [Lat. authoritatem sibi usurpaverit et in nomine proprio venerit], men will follow. Now if any man in philosophy ever came in his own name, Aristotle is that man. (Farrington 113; Works 7.69)

Like Aristotle and the Anti-Christ, Bolingbroke functions in Richard's speeches as "he who, levelling and destroying all that went before, usurps authority to himself and comes in his own name." This illegitimacy is exposed in 4.1, where Bolingbroke imagines a peaceful and dignified transfer of power from Richard to himself in the form of a public abdication: "Fetch hither Richard, that in common view/ He may surrender; so we shall proceed/Without suspicion" (155-57). Richard subverts Bolingbroke's plan when he forces him to grasp the crown with his own hands, to touch the one sacred object he should always revere at a distance: "Here, cousin, seize the crown" (4.1.181). This invitation to desecrate the foundations of a theocratic order is instrumental in triggering off the process of Richard's own victimization. What Richard does is to overlook the presence of Bolingbroke on the stage--he refuses to grant the usurper the treatment bestowed on legitimate monarchs-concentrating instead on the many violations of the crown that have 
been imposed upon him by his enemies. He thus constructs himself as a martyr and a scapegoat:

Now, mark me how I will undo myself.

I give this heavy weight from off my head,

And this unwieldly sceptre from my hand,

The pride of kingly sway from out my heart;

With mine own tears I wash away my balm,

With mine own hands I give away my crown,

With mine own tongue deny my sacred state,

With mine own breath release all duteous oaths ... (4.1.203-10)

What is extraordinarily subversive about this scene is that Richard consciously and repeatedly violates the sanctity of his own anointment: he enumerates one by one the offenses that Bolingbroke and he are committing in carrying out the decoronation act. In a stroke of political genius he shrewdly reverses the initial distribution of roles in the play by rendering Bolingbroke as the abusive usurper and himself as the defenseless martyr: "God pardon all oaths that are broke to me,/ God keep all vows unbroke are made to thee!" (4.1.214-15). The rhyme "me/thee" immediately draws attention to the interchangeability of the positions of deposing and deposed ruler. Not only does Richard ask pardon for what is unpardonable-that he be deposed-but he also announces the vulnerability of Bolingbroke's newly-acquired power. Berger has aptly summarized the complex dynamics at play in 4.1 :

On the one hand Richard formally reenacts the self-deposition he has helped bring about, thereby publicly demonstrating his active relinquishment of the crown. On the other hand he forces Bolingbroke to reenact his usurpation, thereby publicly dramatizing the illegal seizure. The transfer of power is framed as a transfer of guilt. (73)

Act 4 , then, effects a series of political and psychological reversals aimed at questioning the legitimacy of Bolingbroke's claim to the throne. It is in the context of these state rituals for the transfer of power that Richard's patterning of his personal career after a providential design takes on a new purpose. The appearance of this new historical dimension is first hinted at in the play through Richard's interest in having others spread stories of a past Golden Age. He knows there is a genre of literature that focuses on the fall of princes, and accordingly takes delight in his violent fall:

For God's sake let us sit upon the ground And tell sad stories of the death of kings:

How some have been depos'd, some slain in war,

Some haunted by the ghosts they have deposed,

Some poisoned by their wives, some sleeping kill'd,

All murdered-for within the hollow crown

That rounds the mortal temples of a king

Keeps Death his court ... (3.2.155-62) 
Richard goes so far as to declare himself the victim of the crown, a scapegoat who must undergo a disciplinary process so that the crown may be saved. Moreover, he even compares the "deposing of a rightful king" to the crucifixion of Christ: "Though some of you, with Pilate, wash your hands,/ Showing an outward pity-yet you Pilates/ Have here deliver'd me to my sour cross, / And water cannot wash away your $\sin "(4.1 .239-42)$. Other references in the play to Judas betraying Christ or to the redeeming value of martyrdom contribute as well to the overall effect of rhetorically transforming Richard's personal plight into a manifestation of providential history. It is important to note that Richard's self-identification with Christ combines a cyclical view of history (he claims to be typologically reenacting the plight of Christ) with a linear one (this enactment has a very specific goal, the dislodging of Bolingbroke). In this connection, Phyllis Rackin has called attention to the ways in which Shakespeare's play echoes the crucifixion scenes in medieval drama, in which Christ often speaks to the audience from the cross. For Rackin, Richard's deposition is presented "not simply as a re-enactment of a past event but as immediate present action that engages its audience as participants" (270-71).

It is then characteristic of the Christ plot that it tells an exemplary story whose ending is known beforehand. The telos or end-goal of providential history consists of the Second Coming of the Messiah and the damning or redemption of all creatures depending on whether they deserve one fate or the other. Yet the arrival of the Messiah is also--to use a once-fashionable deconstructionist phrase- "always already deferred." The name by which this paradoxical time construct is known in psychoanalytically inflected theories of human time is the "future perfect" or "future anterior" [Fr. futur antérieur]. This is the perfect tense by which the completion of an action is projected and anticipated at the moment of the enunciation: e.g., "By midnight I will have graded at least two-thirds of the exams." The future perfect is also the time of desire, since it enables the speaker to envision imaginatively as complete a reality which has not yet come into being, a process which has not even been launched.

In a maneuver reminiscent of Richard's speeches, Bacon manipulates his reader into accepting that the history of philosophy has evolved around the same pattern as providential history. In both plottings, an idyllic state of prosperity (prelapsarian Eden/ Presocratic philosophy) became corrupted by an illicit act (Adam's temptation and Fall/ Aristotle's "slaying" of Democritus). This fallen state can and will be redeemed by a prophet with messianic powers (Christ/ Bacon). This Messiah knows that his own contemporaries will betray and kill him, and so his mission of redemption is postponed until he makes his Second Coming.

\section{Conclusion: Discovering the Pathos of the Future.}

To what extent do the character of Richard and the philosophical persona of Bacon's shorter treatises respond to the same anxiety about the future? How can their respective constructions of time and subjectivity illuminate each other? First, there is the obvious similarity that both subjects stage a thetorical reaction to forms of authority that allot them a subordinate position. Second, by analogy with providential history, they interpret any 
threats to their project of domination as positive indices of the legitimacy of that project. Bolingbroke's challenge to Richard's absolutist pretensions only reinforces the deposed monarch's conviction that an abused king is, like Jesus Christ, a God-appointed king. In like manner, Bacon identifies the main speakers in his writings with Moses, Daniel, Solomon, and Christ, all of whom are said to be as interested in material progress as in spiritual salvation. Finally, Richard and Bacon conceive of their words as guides which should move posterity to action. For example, in 5.1 of Shakespeare's play Richard entrusts his Queen to turn the event of his deposition into a textual performance, an oral narrative whose audience exists in a sterile future figured as "winter's tedious nights":

In winter's tedious nights sit by the fire

With good old folks, and let them tell thee tales

Of woeful ages long ago betid;

And ere thou bid good night, to quite their griefs

Tell thou the lamentable tale of me,

And send the hearers weeping to their beds;

For why, the senseless brands will sympathize

The heavy accent of thy moving tongue,

And in compassion weep the fire out,

And some will mourn in ashes, some coal-black,

For the deposing of a rightful king. (5.1.40-50)

Richard imagines that his story will move posterity first to pity, and later to action. Since he is bound to die childless, what he hopes to restore in the future is his fame, which (as Quinones reminds us) was one of the Renaissance manifestations of the linear unfolding of time. Richard's lifestory, as told by the Queen, functions then as an announcement of - and a preface to- the rehabilitation of his name.

Bacon also uses a textual image, that precisely of the preface, to argue for the continuation of his project after an unwanted period of interruption:

For himself Bacon was minded not to yield to his own or to anyone's impatience, but to keep his eyes fixed on the ultimate success of the project ... Looking ahead he could see that the stronger and loftier minds, advised by what he now had to offer and without waiting for greater aids, would not only aspire but succeed in achieving the rest for themselves ... But he did not intend to slacken his own efforts ... They needed a preface, and this he hopes the present writing might supply, for that was the intention of every word in it. (Thoughts and Conclusions [Farrington 101])

Both Richard and Bacon explore the possibility that words uttered in the present may provoke a perlocutionary effect in future audiences. The pathos that Richard and Bacon strive for may be an emotional flaw in a king and in an analytical philosopher, but in the leading character of a tragic drama and in a rhetorician it is most certainly an asset. Even if Shakespeare did not mean for Richard to function in this manner, as an onstage character the deposed king does not hide his alternate commitments to a providential and a secular view of history and action, and to forms of self-aggression and self-aggrandizement. That 
is to say, Richard occupies a variety of subject-positions, some of which might have been realized by a receptive audience (be it an audience represented within the play or a group of seventeenth-century English playgoers) in such a way as to construct him as an agent of the historical process which in the text of the play he undoubtedly wishes to influence. In this connection, it must be borne in mind that in the year 1601 the rebellious Lord Essex subsidized a special performance of Richard II at the Globe on the eve of his failed uprising against Elizabeth Tudor. The immediate intention of this production was to impel a select audience composed largely of his fellow conspirators to carry his plans for a deposition into action. The performance was done by the book-using an authorized text-and by a licensed company. As explained by Louis Montrose, the fact that some contemporaneous authorities and writers ascribed such political transcendence to a seemingly innocuous performance has at least three teachings for the student of dramatic literature: (1) that the same text may be seen alternately as politically seditious (the author's intention was to support Bolingbroke/Essex) and politically conservative (his intention was rather to support Richard/Elizabeth); (2) that dramatic characters can be identified by different playgoers with different historical persons (Elizabeth may be alternately identified with Richard and with Bolingbroke); and (3) that any public representation of the dethronement of a king immediately called to mind a series of political events, since the Elizabethan educated classes were used to conceptualizing their historical present in terms of familiar plots (52-56). Indeed, a long-standing concern of New-Historicist critics such as Louis Montrose and Stephen Greenblatt has been the study of how the actions represented in such characteristically early modern genres as historical drama and utopian fiction may influence human actions in a real-world context. The historical Richard II may have failed as a king in his own time, but his eponymous tragic hero (or the actor playing him) may in turn succeed as the leading character in a poignant drama of deposition and posthumous rehabilitation of which he is also the author and stage manager. Similarly, Bacon fails to implement his philosophy in his own time, but promises his readers that it will bear fruit in the future, when it is adopted by a loyal progeny of Baconian scientists.

By way of conclusion, I want to relate this effect of pathos to poststructuralist theories of paradoxical time. Writing on some of Rousseau's and Kant's self-representations, Geoffrey Bennington has shown how a pioneering philosopher's disinterested pursuit of truth is often undermined by arr equally intense concern for reputation (22-25). Both truth and reputation can be momentarily preserved by deferring the moment in which each undergoes the test of experience. The preservation of a certain truth is "made in principle the more secure by [its] temporary renunciation" and by invoking in its place such inducements of "pathos" as the philosopher's self-sacrifice, vulnerability, and even "shameful weakness" (23). In Richard's speeches and in Bacon's early works the audience is invited to experience the speaker's project of self-rehabilitation not as objective truth, but as pathos. What allows this pathos to sustain a self-vindicating argument is the contention that the future realization of the project mirrors an earlier moment of plenitude (Bennington 20-21). In Richard's case, this earlier moment of objectified meaning is Christ's passion, his martyr-like suffering at the hands of his betrayers (Grene 47, 49). Bacon also uses the Christ analogy: Aristotle was an Anti-Christ who killed Democritus, 
whereas Bacon himself is the new Messiah who unmasks and plots the destruction of the Anti-Christ. In Richard's and Bacon's reasonings, if an audience believes in the Second Coming of Christ, why should it not believe in the posthumous triumph of a deposed king or a neglected philosopher?

The use of the future perfect-a future contained in the past, but whose realization is always a deferred event-allows the speaker to claim that he will be posthumously vindicated and reinstated by posterity. As novelist Javier Marías has interpreted it, the Shakespearean future perfect (which he locates in the misquoted verse, "the dark back and abyss of time") is meant to sublimate an experience of loss into one of gain, or at the very least to alleviate that loss:

Lo no venido, esto es, lo no llegado, lo no sucedido, lo no existido, no debemos seguirlo esperando, sino darlo ya por pasado. No [es] que debamos darlo por imposible, ni tampoco descartarlo u olvidarlo sino [darlo] por incorporado a nuestra vida y a nuestro saber ... Y se me ocurre que quizá sea eso, lo que no viene y sin embargo es pasado, lo que discurra por aquella negra espalda y abismo del tiempo ... (35)

That which is still to come ("lo que no viene") yet is perceived as an integral part of the past ("y sin embargo es pasado") describes a well-known strategy of psychoanalysis by which a patient is encouraged to seek by himself the origin of his trauma. While the truth of this trauma manifests itself in the symptoms of the patient's present disorder-its cause lies buried somewhere in his past--the elucidation of its meaning is posited as taking place in an unspecified future-it is a deferred event. As a result of this double bind, "[t]he duration of [the analysis] can only be anticipated for the subject as indefinite" (Lacan 95-96). To be sure, Richard and Bacon foreshadow each in his own way the strategy of connecting the moment before the trauma/ fall (when neither Aristotle nor Bolingbroke had yet made his appearance) with the moment when the trauma is overcome by means of the assurance that Aristotle and Bolingbroke will be dislodged. For both Richard and Bacon, the most immediate motivation behind this unusual way of conceptualizing time and history may be to seek consolation for the traumatic realization of their subordinate positions in relation to their antagonists. At the same time, however, their paradoxical account of time seeks to create (in the eyes of others) the representation of a historical process as both inevitable and hard-won. Such is the import of Richard's "I will be acknowledged as a lawful king whereas Bolingbroke's lineage will be damned," and of Bacon's "My philosophy will in time dislodge that of Aristotle." By deferring the realization of their respective prophecies, both speakers protect themselves from the objection that the force of their arguments lies not in the empirical value of the truth they advocate, but simply in the seductiveness of their rhetoric. In other words, they protect themselves from the charges frequently leveled against the character of Richard to the effect that he is not an onstage king with a clearly defined political project, but simply a self-pitying and sentimental poet. 


\section{Notes}

1. All references to the text of King Richard $I$ are to Peter Ure's edition for the Arden series, and will be indicated at the end of each quotation or paraphrase by line number rather than page.

2. In chapter 1 of The Renaissance Discovery of Time, Quinones discusses these three sets of images, along with a fourth one absent from Richard II-secular education-as metaphorical languages by which the new consciousness of secular time was explored in the early modern period.

3. Bolingbroke was known in his own time as a "devoted son and father" (Goodman 156). For two very brief yet very useful biographies of Henry Bolingbroke see Hallam 93-94 and chapter 9 of Goodman.

4. Quinones further argues that in moving from Richard II and 1 \& 2 Henry IV to the great tragedies, Shakespeare shifted from a dramatic universe in which chaos and order compete for dominance, to one of inevitable skepticism and nothingness (Renaissance Discovery 324). Collins puts forward a similar interpretation, affirming that Bolingbroke's efforts to establish a stable social order ultimately defeat Richard's desperate attempts to reduce secular time to an "illusion of immutability" (52-54).

5. For a sound rejoinder to Quinones's literalizing biblical reading, see Liebler 461-62.

6. In chapter 2 of his book Goodman discusses the two Appeals of Treason that were presented by the so-called lords appellant in the parliaments of 1386 (against Richard's chancellor) and 1388 (against many of his principal advisers, who were executed and replaced by a council of control). These attempts proved unsuccessful, since Richard dismissed the councillors in 1389, and ruled with the support of John of Gaunt until his uncle's death in 1399. The actions depicted in Shakespeare's play take place between the years 1398 (when Richard shakes off the influence of the last two lords appellant, Mowbray and Bolingbroke, by banishing them from the realm) and 1400 , when Richard dies in prison.

7. Barkan (18-19) and Leggatt (72-74) have explored the rapid Ricardization of Bolingbroke as soon as he seizes power. In becoming another Richard, the legitimacy of his claim to the throne is seriously undermined. Much of the work done on Richard II in the past half-century (including Tillyard's essay) has tried to come to terms with the abrupt discontinuities in character, theme, plot, and even diction that take place especially between the end of Act 2 and the rest of the play. The classic formulation of the argument for considering Richard II to be a clumsily written play appears in Rossiter.

8. For a recent statement of this generalized view of Richard, see Eagleton's troubling account of the deposed king's "linguistic inflation" as simply a failed attempt to impose his verbalized desires on a real world that is insensitive and impermeable to those words (9-15). See also Pye 86.

9. Compare Tennenhouse, who on the mistaken assumption that Bolingbroke skillfully controls the deposition scene, goes so far as to depict him (to the detriment of Richard) as the character "in whom Shakespeare invests the power of the artist" (81).

10. The most thorough analysis of Richard's formulary and intransitive manner of speech takes place in chapter 3 of Porter's study, especially 29-37. As much as I admire Porter's conceptualizing effort, I cannot agree with the conclusion at which he arrives: he sees the features of Richard's speech as indices of his "general refusal to take cognizance of the fact of time or of anything that exists through time (such as the right of succession)," as well as his "profound powerlessness" (35). Unlike Porter and the proponents of the "poet-king" thesis, much recent theorizing on speech acts would allow that persons or characters invested with some kind of legal authority have the power to create the realities that they name (Bourdieu 42, 223-24). 
11. Here I am rephrasing the traditional terms of the politico-theological discussion of the king's two bodies (Kantorowicz 24-41). Where Kantorowicz sees a violent separation of the mortal physical body and the immortal body politic of the king (an act of political treason and religious heresy), I see Richard's recognition of the arbitrariness of that union.

12. "Ritual repetition" alludes of course to Freud's own "repetition compulsion," a concept he uses to narrativize the dialectical relation between the subject's present pain and his willed pleasure. See especially Beyond the Pleasure Principle (40-47) and "Remembering, Repeating, and Working-Through."

13. Elsewhere Bacon alternates the Anti-Christ plot with that of Adam's Fall, which allows him to interpret the centuries-old stagnation of philosophy as humankind's loss of dominion over nature. Correspondingly, he argues that the contemporary geographical and scientific discoveries are an unequivocal indication of humankind's imminent arrival at the Mosaic earthly paradise. The locus classicus of this argument appears in chapter 1 of Valerius Terminus of the Interpretation of Nature [1603; publ. 1734] (Works 6. 27-29). For commentaries on this plot see Blumenberg 383-87; Guibbory 46-49, 60.

14. See Kantorowicz 35-39 for a reading of this scene that emphasizes Richard's "guilt" for having betrayed the crown (he is both a Christ and a Pilate figure). Another proponent of the guilt thesis is Pye, who argues extravagantly that Richard seems aware of having committed a crime which he cannot fully articulate, and consequently experiences a "shame beyond shame" (97-98).

15. Among the most useful readings of 4.1 are those by Berger (47-73) and Leggatt (67-69).

16. In $A$ Theater of Envy René Girard has argued that the various types of mimetic or emulous desire characteristic of so many of Shakespeare's plays create an environment of competition which can only be controlled by periodically having one or more characters commit an act of arbitrary violence. Unfortunately, the only English history play Girard subjects to this type of analysis is Richard III. Following Murray Krieger and Jan Kott, Girard argues that the climate of mutual enmity and violence brought about by the War of the Roses blurred the distinctions between legitimate and illegitimate rulers. In a system where no one is innocent, an unstated consensus must be achieved on who will be arbitrarily sacrificed (253). Unlike conventional scapegoats, however, Richard II willingly accepts his victimization provided that he can make it known to posterity that he was maliciously sacrificed. Building on Girard's work, Greenberg has studied the "ritual killing" of the "king/ victim" character in English and Continental Renaissance drama (xxxiii-xxxviii).

17. For an informative survey of Renaissance theories of cyclical history see Guibbory's Introduction to The Map of Time, especially 8-17. Liebler grants the Cain-and-Abel narrative a resonance as powerful as the one $\mathrm{I}$ assign to the Christ plot (467-69).

18. I have opted for a very general definition of this concept for the reason that it has received multiple and widely divergent treatments in the writings of Sigmund Freud (The Interpretation of Dreams 621), Jacques Lacan (Écrits: A Selection 86, 306), Jacques Derrida (Dissemination 7; "Racism's Last Word" 330), Catherine Clément (The Lives and Legends of Jacques Lacan 12223), and Geoffrey Bennington ("Toward a Criticism of the Future" 17-20), among others. See also the two lively collections of essays on paradoxical time edited by Sima N. Godfrey (especially the Editor's Preface and Richard Klein's piece) and David Woods (especially the essays by Geoffrey Bennington and Dennis J. Schmidt). For applications of the "future perfect" construct to Renaissance texts, see Berger 119-21; Garber 306-9; Goldberg 204.

19. Political sociologists who have accepted the findings of various strands of speech-act theory and of structuralist anthropology have arrived at similar conclusions regarding the mutual influence of play-world and real-world actions. Thus, a treatment of political prophecies and 
utopias congenial to the postulates of the New Historicism takes place in chapter 5 of Bourdieu, especially $127-29$.

20. Some of the most perceptive and nuanced readings of the play are flawed by their hopeless tendency to treat as interchangeable the different entities evoked by the signifier "Richard": a fictional character and an actor (these are onstage entities), and a historical person called Richard II and an Elizabethan author called William Shakespeare (these are offstage entities). A case in point is Blanpied 120-40.

21. Marías seems to have modernized a line from the second scene of The Tempest, where Prospero interrogates his daughter Miranda about her half-forgotten, half-repressed memories of a past which is bound to return to her in the course of the play's action: "What seest thou else/ In the dark backward and abysm of time?/ If thou remembrest aught ere thou cam'st here,/ How thou cam'st here thou mayst" $(1.2 .49-52)$.

22. This paragraph is indebted to Klein's discussion of what he calls the "anticipatory author."

\section{Works Cited}

Bacon, Francis. The Works of Francis Bacon. 15 vols. Ed. James Spedding, Robert Leslie Ellis, and Douglas Denon Heath. Boston: Brown, 1861.

Barkan, Leonard. "The Theatrical Consistency of Richard II." Shakespeare Quarterly 29 (1978): 5-19.

Bennington, Geoffrey. "Toward a Criticism of the Future." Woods 17-29.

Berger, Harry, Jr. Imaginary Audition: Shakespeare on Stage and Page. Berkeley: U of California P, 1989.

Blanpied, John. Time and the Artist in Shakespeare's English Histories. Newark: U of Delaware P, 1983.

Blumenberg, Hans. The Legitimacy of the Modern Age. Trans. Robert M. Wallace. Cambridge: MIT P, 1983.

Bourdieu, Pierre. Language and Symbolic Power. Trans. Gino Raymond and Matthew Adamson. Ed. John B. Thompson. Cambridge: Harvard UP, 1991.

Champion, Larry S. "The Noise of Threatening Drum": Dramatic Strategy and Political Ideology in Shakespeare and the English Chronicle Plays. Newark: U of Delaware P, 1990.

Clément, Catherine. The Lives and Legends of Jacques Lacan. Trans. Arthur Goldhammer. New York: Columbia UP, 1983.

Collins, Stephen L. From Divine Cosmos to Sovereign State: An Intellectual History of Consciousness and the Idea of Order in Renaissance England. New York: Oxford UP, 1989.

Derrida, Jacques. Dissemination. Trans. and ed. Barbara Johnson. Chicago: U of Chicago P, 1981. "Racism's Last Word." Trans. Peggy Kamuf. "Race," Writing, and Difference. Ed.

Henry Louis Gates, Jr. Chicago: U of Chicago P, 1986. 329-38.

Eagleton, Terry. William Shakespeare. New York: Blackwell, 1986.

Farrington, Benjamin. The Philosophy of Francis Bacon: An Essay on Its Development from 1603

to 1609 with New Translations of Fundamental Texts. Chicago: U of Chicago P, 1966.

Freud, Sigmund. Beyond the Pleasure Principle. 1920. Trans. James Strachey. New York: Bantam, 1959.

The Interpretation of Dreams. 1900. Vol. 5 of The Standard Edition of the Complete Psychological Works of Sigmund Freud. Trans. James Strachey. London: Hogarth, 1955. 
" "Remembering, Repeating, and Working-Through." 1914. Vol. 12 of The Standard Edition of the Complete Psychological Works of Sigmund Freud. Trans. James Strachey. London: Hogarth, 1955. 147-56.

Garber, Marjorie. "'What's Past Is Prologue': Temporality and Prophecy in Shakespeare's History Plays." Renaissance Genres: Essays on Theory, History, and Interpretation. Ed. Barbara Kiefer Lewalski. Cambridge: Harvard UP, 1986. 301-31.

Girard, René. A Theater of Envy: William Shakespeare. New York: Oxford UP, 1991.

Godfrey, Sima N., ed. The Anxiety of Anticipation. Spec. issue of Yale French Studies 66 (1984). Goldberg, Jonathan. "Dating Milton." Soliciting Interpretation: Literary Theory and Seventeenth-

Century English Poetry. Ed. Elizabeth D. Harvey and Katharine Eisaman Maus. Chicago: U of Chicago P, 1990. 199-220.

Goodman, Anthony. The Loyal Conspiracy: The Lords Appellant under Richard II. Coral Gables: U of Miami P, 1971.

Greenberg, Mitchell. Canonical States, Canonical Stages: Oedipus, Othering, and SeventeenthCentury Drama. Minneapolis: U of Minnesota P, 1994.

Grene, David. The Actor in History: Studies in Shakespearean Stage Poetry. University Park:

Pennsylvania State UP, 1988.

Guibbory, Achsah. The Map of Time: Seventeenth-Century Literature and Ideas of Pattern in History. Urbana: U of nlinois P, 1986.

Hallam, Elizabeth, ed. The Plantagenet Encyclopedia. New York: Viking, 1990.

Kantorowicz, Ernst H. The King's Two Bodies: A Study in Medieval Political Theology. Princeton: Princeton UP, 1957.

Klein, Richard. "Under 'Pragmatic' Paradoxes." Godfrey 91-109.

Lacan, Jacques. Écrits: A Selection. Trans. Alan Sheridan. New York: Norton, 1977.

Leggatt, Alexander. Shakespeare's Political Drama: The History Plays and the Roman Plays. London: Routledge, 1988.

Liebler, Naomi Conn. "Shakespeare's Medieval Husbandry: Cain and Abel, Richard II, and Brudermord." Mediaevalia: A Journal of Medieval Studies 18 (1995): 451-73.

Marías, Javier. "La negra espalda de lo no venido." EL PAISS 29 December 1996: 35.

Montrose, Louis. "Shakespeare, the Stage, and the State." SubStance 80 (1996): 46-67.

Porter, Joseph. The Drama of Speech Acts: Shakespeare's Lancastrian Tetralogy. Berkeley: U of California P, 1979.

Pye, Christopher. The Regal Phantasm: Shakespeare and the Politics of Spectacle. New York: Routledge, 1990.

Quinones, Ricardo J. The Changes of Cain: Violence and the Lost Brother in Cain and Abel Literature. Princeton: Princeton UP, 1991.

The Renaissance Discovery of Time. Cambridge: Harvard UP, 1972.

Rackin, Phyllis. "The Role of the Audience in Shakespeare's Richard II." Shakespeare Quarterly 36 (1985): 329-44.

Rossiter, A.P. "Richard II." Angel with Horns and Other Shakespearean Lectures. By Rossiter. Ed. Graham Storey. London: Longmans, 1961. Rpt. in Essays in Shakespearean Criticism. Ed. James L. Calderwood and Harold E. Toliver. Englewood Cliffs: Prentice-Hall, 1970. 171-83. Schmidt, Dennis J. "Circles-Hermeneutic and Otherwise: On Various Senses of the Future as "Not Yet." Woods 67-77.

Shakespeare, William. King Richard II. Ed. Peter Ure. The Arden Shakespeare. Cambridge: Harvard UP, 1956.

The Tempest. Ed. Frank Kermode. The Arden Shakespeare. London: Methuen, 1958. 
Sinfield, Alan. Faultlines: Cultural Materialism and the Politics of Dissident Reading. Berkeley: U of California P, 1992.

Tennenhouse, Leonard. Power on Display: The Politics of Shakespeare's Genres. New York: Methuen, 1986.

Tillyard, E.M.W. "Richard II." Shakespeare's History Plays. London: Macmillan, 1946. Rpt. in Shakespeare: Modern Essays in Criticism. Ed. Leonard F. Dean. Rev. ed. New York: Oxford UP, 1967. 167-87.

Wilson, Richard. Will Power: Essays on Shakespearean Authority. New York: Harvester/ Wheatsheaf, 1993.

Woods, David, ed. Writing the Future. London: Routledge, 1990. 